\title{
THE STUDY OF THE FEATURES OF ESTONIAN ECONOMIC GROWTH: THE EXPERIENCE FOR UKRAINE
}

\author{
Andrii Krysovatyi \\ Ternopil National Economic University \\ 11 Lvivska str., Ternopil, Ukraine, 46020 \\ kai@tneu.edu.ua \\ Oleksandra Vasylchyshyn \\ Department of Taxation and Fiscal Policy \\ Ternopil National Economic University \\ 11 Lvivska str., Ternopil, Ukraine, 46020 \\ volexandra@gmail.com
}

\begin{abstract}
The authors have studied the features of Estonia economic growth that started from the successful money reform then the taxation reform correspondingly after the World economic crisis with anti-crisis reforms. It was established, that for today the base of Estonian economy development is a creation of digital society e-Estonia, the unique commercial register and the register of real estate. The features of Estonia taxation system, characterized with relatively low taxes and easiness of the use, were also defined in the work; the features of bank system, which financial safety essentially depends on Sweden banks that in their turn depends on inflation and economic situation in the country, were studied. The work also analyses the state of economic growth in Estonia in six stages, each of which has its cause and result. The first, third and fifth stages were with negative GDP index that was correspondingly caused by introduction of the money, taxation reform and the World economic crisis. The second, fourth and sixth stages were characterized with economic growth with positive GDP index that proves the expedience and effectiveness of introduction of the money, taxation and anti-crisis reforms in the country.
\end{abstract}

Keywords: economic growth, taxation system, bank system, financial safety, digital society.

\section{Introduction}

The Estonian economy is for today open and stable with high ability to introduction of different innovations. Estonia follows the conservative budgetary policy, has taxation system, one of the best in European Union, balanced bank system, gives foreign citizens the significant right for land possession and provides 100-percent transfer of profit. So, Estonia is the one of most favorable countries for business.

In the period of economic crisis Estonia succeeded in principally-structured reforms, especially as to legislation, most liberal in EU. The effectiveness of financial policy was proved by the fact that after the long period of decline Estonia succeeded in observance of certain requirements to join the Eurozone.

It must be noted, that for today Estonian legislation is well harmonized with EU one. Estonia is most transparent and least corrupted state in the Central and Eastern Europe (index of corruption according to Transparency International for 2015 was 23 place among 168 [1]). Estonia also has the highly developed e-communications: good access to the internet, ID-cards, online-projects and also has relatively good production infrastructure, fast developed and modernized (ports, roads, telecommunications, storage facilities). The economic freedom in this state is on the one of first places in the World and on the first place in the Central and Eastern Europe region (the world level of economic freedom in 2015 was 8 place of 178 countries [1]), at that the normative environment favors the opening and conduct of business in Estonia (according to IMF report as to the facility of conducting business in 2015, 16 place of 189 countries [1]). At that Estonia occupies the high international credit ratings (Standard \& Poor`s: AA-, Moody`s: A1, Fitch: IBCA: A+ [1]). The experience of Estonia is rather interesting for Ukraine that is directed on eurointegration. As a result, the study, outlining and correct implementation of certain steps from the experience of Estonian economic growth in legislative, tax and bank spheres allow Ukraine to adapt in EU. 


\section{Analysis of literary data and outlining of problem}

Many scientists and leading economists studied the experience of Estonian economic growth. Especially Friedel Taube and Olena Perepadya underline in their works that Estonia develops not only in the segment of IT-industry, but accent that this Baltic country is an exemplary EU member also in other branches [2]. According to the last data of European commission, Estonia demonstrated the least level of newly created indebtedness comparing with own GDP among the other EU state-members in 2012 - only 0,3 percent. The Baltic state is followed by Sweden, Bulgaria and Luxemburg. For comparison: Spain has accumulated the new debts as 10,6 percents of own DGP in 2012. Even the estimation of general debt loads of Estonia testifies to its exemplary successes in economy - the state debt of Estonia is 10,1 percents to GDP and is the lowest in Europe [3]. Mart Laar the head of supervision council of the Bank of Estonia, the prime-minister of Estonia (1992-1994, 1999-2002), the defense minister of Estonia (2011-2012) accents that Estonia grew faster than any other EU state-member and states that other countries must use the new technologies and techniques, because the overtake needs to forget the old things, even ones, used in developed countries, and to concentrate on the new methods [2]. Mychailo Mikytyn sums up in his research that Estonia is a rather good sample for imitation of reforms, especially for the countries, appeared after decades of communistic enslavement [4]. Hanna Korbut and Taavi Roivas, the present prime-minister of Estonia, accent that Estonia became a member of EU and attained the economic growth especially due to the reforms [5]. Hanna Savina separates the main seven principles, necessary to build the functioning e-government, and states that the number of "e-Estonians" will exceed 10 million till 2025 [6]. Timophiy Kramariv in his research regards the introduction of Estonian experience of economic growth in Ukraine skeptically, not because of its ineffectiveness, but because of unwillingness of existing native corrupted officials to introduce the personal e-cards, to create the digital society [7].

\section{Aim and tasks of research}

The aim of this work is to study the features of economic growth in Estonia as an experience for Ukraine.

The following tasks were defined for attaining the set aim:

1. To study the economic growth of Estonia from 1991 to 2016.

2. To define the features that favored or restrained the Estonian economic growth.

3. To estimate the influence of the state of taxation and bank systems on Estonian economic growth.

4. To outline the possibilities to implement the experience of Estonian economic growth in the economy of Ukraine.

\section{Materials and methods of research}

The materials of research were the statistical data of Trade-industrial house of Estonia, Taxation-Custom Department of Estonia, Central bank of Estonia, e-resources, scientific-pedagogical periodic.

The empirical data of the study of economic growth in Estonia allow separate six stages, characterized with certain specificity of influence of reforms or crises. As a result three periods had negative GDP under the influence of money reform introduction at the first stage, taxation reform at the third stage and the World financial crisis at the fifth stage. Correspondingly, the second, fourth and sixth stages of Estonian economic growth are characterized with positive GDP that testifies to the effectiveness and success of introduction of the money, taxation and anti-crisis reforms in the country.

The certain efficient factors that finally favored the Estonian economic growth were determined as the method of analysis of the taxation and bank system.

\section{Results of research}

In 1991 after the Soviet Union destruction, Estonia started to be renewed as an independent republic. As far as the reforms were rather weak for that time, the first years of Estonian indepen- 
dence were characterized with essential economic problems. The industrial production has fallen at the beginning of 1993 by $45 \%$ comparing with 1989 (last year of the "old" economic regime). In 1992 the inflation in Estonia exceeded $1000 \%$, and the living standards essentially decreased.

The preconditions for further reforms were weak, $80 \%$ of economy belonged to the state and the experience of private property possession was absent. The country depended on Russian energy sources, $92.5 \%$ of its trade was with Russia and the export to the Western Europe was minimal. The countries of the Central-Eastern Europe started certain economic reforms before the complete economic destruction. The aims of transfer were different in different countries. The main aim of Estonia was the strengthening of its sovereignty, reorientation of the country from the East to West and Integration to the European Union (EU) and North-Atlantic Treaty organization (NATO). Estonia must do the following for it:

1. To create the working democracy with effective institutions (the necessity of new Constitution, radical reform of the state government and decrease of corruption).

2. To pass from the command economy to the market one.

3. To increase the Estonian living standards up to EU level.

4. To group and integrate the Estonian society (the necessity to assure Estonians in future, to protect their language and culture and also to integrate the ethnic population).

The real transitional reforms started in summer of 1992. The first radical reform was the money one, accepted in May of 1992 and realized the 20 of June of 1992. The leading economic problem of 1992 was hyperinflation. Estonia was directed on restoration of own national monetary unit as fast as possible. The idea of monetary council, authorized by Estonian parliament in May of 1992 appeared in several places at the same time. The main cause of such a choice was its easiness. It seemed to be true that it is the most effective means of the fight against inflation, because it needed from the government to support the fixed currency exchange course and the balance of state budget and also prohibited to the Bank of Estonia to credit the state. At the very beginning the Council promised that the crown would be converted that coincided with the Estonian choice of free external trade. At the beginning the International Monetary Fund (IMF) resisted the idea of monetary council creation, preferring the traditional bank that has permission for giving internal credits, but IMF was compelled to accept such decision of Estonia (Gansson and Sax, 1992; Lainela and Sutela, 1994) [2].

The new Estonian Government also tried to change the court system completely. As far as the law was under the influences of German juridical tradition since Hanseatic time, and as far as Estonia wanted to join the European Union, the government has chosen Germany as a model of its juridical system. Estonia simply introduced the German civil and commercial codes to provide the correspondence of its legislation to EU standards. 19 acts were accepted to construct the modern European three-level court system.

The economy liberalization was the first step for all transitional economic formations of the Central and Eastern Europe. As a result, liberalization often led to the abrupt growth of inflation speed and abrupt worsening of economic conditions as it took place in Estonia. The policy of openness created the environment of transparence with distinct signals, given to the producers by the market. The openness also favors subcontracting that gives a possibility to use the high-qualified but cheap working force that exists in transitional economic formations. Estonia has liberalized its trade policy already at the beginning: almost all export limitations were eliminated for 1992. The liberal trade policy favored the export growth and gave to the country a possibility to earn the foreign currency, so needed for import. Estonia also eliminated all import tariffs, except tobacco, alcohol and fuel that the custom was introduced for (Gansen and Sorsa, 1994) [2]. These brave steps caused the serious discussions in Estonia and beyond it. When Estonia started the negotiations with European Union about free trade in 1994, the representatives of EU could not believe that the economy without any custom tariffs can exist. They spent the whole day for studying all correspondent acts and regulations and for being convinced that it is really possible.

The former Soviet republic surprised the experts-economists throughout the World with economic growth by more than 10 percents at the end of 1990-ies and at the beginning of 2000-ies. 
At that time Estonia was called "The Baltic tiger". The professor Riner Kattel, the one of most famous Estonian politologists-economists of the present time thinks, that among the most significant factors of Estonian success is its geographic location side by side with Finland and Sweden. It is not only the flows of tourists but also technologies and investments. The export in these countries is called just the base of Estonian economic growth: 23 percents of export belong to Finland, near 15 to Sweden, correspondingly [3].

In 2016 Estonia received the 23-th place among 141 countries in the Global Innovation Index. The rating is leaded by Switzerland, Great Britain and Sweden; Finland is on the 6-th place.

Estonia takes part in the production of high-technological equipment as a part of production chain. The role of the country in direct elaboration of innovative products is insignificant. Estonia plays the role of cheap production subdivision for many leading companies. Estonian IT-sector turned out to be oriented mainly on the local market. The low competitiveness of internal market limits the income of Estonian companies. It is worth to be noted, that in 2016 Japan became the first big country that has introduced the personal code My Number and electronic ID-card, based on it.

As a result, the Estonian economic development can be divided in several stages by GDP growth. The first stage from 1991 to 1994 was characterized with establishing, at which the money reform was realized, and GDP was from $14 \%$ to $-2 \%$. The second stage (1995-1998) was characterized with economic growth as a result of reform and GDP reaches almost $12 \%$. The third stage (1999) was characterized with introduction of the new system of enterprises profit taxation that resulted in minus GDP index $(-0,3 \%)$, but proved that this taxation system provided the following stable economic growth for 8 years that can be characterized as the fourth stage (2000-2007). Obviously, the World economic crisis influenced also the Estonian economy that determined the fifth stage, at which GDP index reached the mark $-14,3 \%$. The sixth stage that lasts till today can be characterized as after-crisis one. Due to the correct anti-crisis arrangements GDP growth was restored and in 2011 it was 7,5\%, and since 2013 is kept on the level near $2 \%$.

The defined stages distinctly prove the correctness of accepted reforms in Estonian legislative sphere, especially in taxation and bank systems that led to the effective economic growth in the country. Let's consider the features of these systems.

As to the Estonian taxation system, let's note that the Single tax was firstly introduced in 1994 with rate 26 percents. The rate gradually decreased since this time and is now 20 percents. Somebody thinks that the most surprising aspect of Estonian single tax is its easiness. 5 minutes are enough to pay taxes in Estonia. The code includes completely integrated tax from the natural persons and corporative incomes. It means that the corporative profit is taxed only once at individual level or at the level of person. That is the Estonian single tax is much better for the growth than the American system that suffers from the destructive double taxation. In whole, the tax rate for corporative profit is $20 \%$ in Estonia (the integrated tax rate for corporative profit in USA is $56 \%$ ). The taxation system in Estonia looks more progressive than in the USA, not to mention Italy, Greece or Mexico.

The taxation institution that collects the state taxes is for today the Taxation-Custom department that functions in the sphere of financial ministry management. The tax officers must confirm the correctness of tax payments, to estimate the sums of taxes and determine the percents for payment in cases, established by law, surcharge the debts on taxes and use sanctions against the disturbers of tax legislation.

The aim of the modern Estonian tax policy is the transfer of tax load from the working force to consumption sphere. Let's note that the unique system of tax on enterprise profit functions in Estonia since 2000 that is the whole undistributed enterprise profit is not taxed. At that the local taxes play insignificant role in Estonian taxation system. Most (in 2014 - 96 \%) annual declarations of physical persons are given in e-form. The Estonian legislation as to VAT is based on EU declarations about the general system of VAT (2006/112/EU). The standard VAT rate is $20 \%$, and lowered rate is $9 \%$. The mechanism of reverse taxation is also used in Estonia and so on.

It must be noted that the significant stimulus for formation of the open and transparent working environment in the country, interesting for investors, is a creation of unique commercial register and the register of real estate that eliminate any doubts as to the subordination and proper- 
ty right. At the same time the Estonian government gives a possibility to study the unprecedented volume of tax information in the internet, using the most modern technologies.

As to the bank system, for today the central bank of Estonia is EestiPank that is the upper level of two-level system of Estonian credit institutions. After the transition of the Estonian economy to the euro in 2011, it maintains prices in the domestic market and conducts general control and supervision over the activities of the country's banks, now the exchange rates are regulated by the Central European Bank [8]. It functions as prescriptive and control organ, it control all agreements for more than 50000 euro and also the cash volume, credit rates and price policy of credit institutions. The currency courses after Estonia accession to Eurozone are regulated by the Central European Bank. 90 \% of Estonian bank sector is divided between two largest Sweden banks - Swedbank AS and SEB Pank AS. Both banks belong to the large concerns, have successful history and guaranteed Sweden confidence. The spectrum of services, given by these banks, is very wide: multicurrency accounts, credits, factoring, bill of credit, investments in stock and precious metals, different payment cards, internet-banking, deposits and so on. Swedbank is comfortable because its branches and cash machines are in many countries of former CIS and Europe.

Both banks open the accounts for nonresidents of Estonia, in client's presence or distantly. For creating accounts of the offshore companies the client's personal presence and interview with bankers are needed.

$10 \%$ of Estonian market is divided between 5 more banks and several branches of foreign ones, namely: Krediidipank, TallinnaÄripank, SampoPank - is in DanskeBank group - most Scandinavian concern, MarfinPank - from April of 2012 more than $70 \%$ of safety stock belong to UKRSELHOSPROM PCF LLC. It is rather popular bank; it has offices in many countries. It gives most number of bank services to the residents and nonresidents of Estonia.

E-banking system is highly developed in Estonia; almost $80 \%$ of all dwellers of the state realize their everyday bank operations using the internet. Banks also develop and spread the possibilities of bank operations using mobile telephone through WAP system.

But it must be noted that if the risks of Sweden market grow, they will influence also the Estonian market of bank services and bank system as a whole. Such presence of Sweden capital in Estonian bank system to certain extent testifies to the low level of financial safety of Estonian bank system.

Especially, the banks and branches in third quarter of 2016 have gotten a profit $81 \mathrm{mln}$ euro that is by $9 \%$ less than in the second quarter. The incomes of bank sector were by $10 \%$ less. The other incomes shortened most of all that are the ones that abruptly grew in the second quarter at the background of commercial agreement of several banks that they received the extraordinary profit from. Without accounting these agreements the profit of third quarter could be by $23 \%$ more than in the second one. Among the most important kinds of incomes, the incomes from interests increased by $3,5 \%$ for quarter and the incomes from services - by $0,4 \%$. Let's note that the ratio of outlays and incomes increased a little and reached 48,3\%.

Despite the negative Euribor indices, the banks increased the incomes from interests and kept profitability mainly due to the fast growth of crediting and arrangements, carried out in managerial sphere. As far as netto-incomes from interests increase slower than the excess of credit portfolio, the indices of pure interest margin decreased.

The part of nonresidents' savings essentially shortened during the third quarter, the savings of offshore and other regions decreased. As far as nonresidents' savings are very volatile, such tendencies increase the stability of bank resources and decrease the liquidity risk. The outflow of nonresidents' savings influences among other things the general increase of savings balance that was lower than usually during the last year.

The annual growth of credit portfolio of Estonian banks in the third quarter of 2016 became slower from 11,7 to $9,4 \%$. And the annual savings growth became faster from 2,2 to $3,6 \%$. The banks liquidity was strong and continued to be improved and was in this period $19,8 \%$ from own banks assets, at the same time the banks have other liquid assets as 7,7\% of assets. The bank resource of the third quarter grew by $1,4 \%$ up to 20,8 bln euro. The productivity of own capital of Estonian banks in the third quarter was kept at the level $12 \%$ [9]. 
According to the autumn economic prognosis of Eurocomission, the Estonian economy will grow by $1,1 \%$ this year, but the external demand can stimulate it in further. The inflation and unemployment will remain at the low level and the state budget will remain balanced. In the Eurozone and European Union in general the slow growth will go on. In 2018 the Eurocomission prognoses $2,3 \%$ of economic growth for Estonia, but inflation will also increase from today $0,8 \%$ to $2,6 \%$. The unemployment level in nearest years must remain low (this year 6,5\%; next year 7,4 \%), and budget will remain balanced (this year $0,5 \%$ of GDP; in 2017 year $0,4 \%$ of GDP). According to the prognosis of next year, the economy of European zone will grow on average by $1,5 \%$, and in whole European Union - by $1,6 \%$. The indices of current year - 1,7 \% and 1,8 \% respectively. Most probably, the economic growth in EU will also remain insignificant in further [10].

Up to 2018 the private consumption will remain the main stimulus of growth, supported also by the expected improvement of employment level and little increase of salary. The general deficit of Eurozone budget must slowly decrease, whereas the fiscal policy is expected to remain soft and investments will correspondingly increase.

The political instability, the slow economic growth beyond EU and weak global trade can decelerate the growth prospects. There is also a threat that the growth will be decelerated by the low economic results of last years. Next years the European economy will not get the external support such as the decline of oil prices and decrease of currency course.

Although the economic results are essentially different as it were earlier, today GDP in EU is at the pre-crisis level, and in some state-members of EU even by $10 \%$ more than at decline. During the whole prognosis period the economic activity in all EU state-members must gradually accelerate but will remain uneven.

\section{Discussion of results}

At studying the set aim we want to accent the topicality and necessity of Estonian experience of economic growth as to introduction in Ukraine. But the problem of this research is rather interesting and wide and needs more detail study in further. The given analysis of Estonian taxation reform must be used in Ukrainian taxation system and the money reform correspondingly in the bank system of Ukraine. The study about the introduction of Ukrainian digital society is important, but the features of its implementation in Ukraine need further analyzes and researches.

\section{Conclusions}

As a result of research:

1. The work analyses the state of economic growth in Estonia in six stages, each of which has its cause and result. The first, third and fifth stages were with negative GDP index that was correspondingly caused by introduction of the money, taxation reform and the World economic crisis. The second, fourth and sixth stages were characterized with economic growth with positive GDP index that proves the expedience and effectiveness of introduction of the money, taxation and anti-crisis reforms in the country that is a good example for Ukraine.

2. The functioning e-government must be built in Ukraine to differ one citizen from another. In Estonia it is realized using the universal ID-card. It is used to authorize on the sites of banks, Taxation-Custom department, other state organizations and hospitals - in general four thousand different services can be used - from the purchase of license for fishing to the payment for public transport usage. To give people a possibility to interact with state directly, the government permitted in 2000 year to sign any documents by digital signatures. The Estonians have left more than 200 million autographs since this time.

3. Ukraine must develop the local companies instead of using the foreign results. Estonia doesn't pay for license to the great international IT-companies: the free software and the results of local companies are used in the country. The big data allow analyze the context and to offer services to each user individually. For example the "context services" can be given - the one or other possibilities are offered to the users, depending on their personal situation.

4. Ukraine must apply many efforts for dwellers begin to use e-services as more as possible. For that the great attention must be paid to the teaching of computer literacy. In Estonia all schools 
have access to the internet since the end of 1990-ies. At the same time Tiigrihüpe fund, created by the government for supporting the new technologies, taught the programming in senior classes, and recently its leaders offered the methodology of teaching computer literacy for pre-school children. The government also makes investments in the education of old generation that is a good example for Ukraine.

All these innovations will return the population confidence to the government and as a result the economic growth in Ukraine will be restored.

\section{References.}

[1] Estonianexporters\&importers 2016 (2016). Estonian Chamber of Commerceand Industry, 416.

[2] Laar, M. Estoniya. Nayradykal'nishi reformy. Available at: http://www.ukrainereforms.info/ wp-content/uploads/2015/04/AA-GR_-_Ch_04.pdf

[3] Taube, F., Perepadya, O. (2013). Estoniya - zrazkova uchenytsya Yevrozony. Available at: http:// www.pravda.com.ua/inozmi/deutsche-welle/2013/07/5/6993654/

[4] Mykytyn, M. Pryklad Estoniyi dovodyt', shcho rozumne opodatkuvannya spryyaye zrostannyu ekonomiky. Available at: http://informal.com.ua/western-view/estoniya-pokazuje-yak-rozumne-opodatkuvannya-spryyaje-zrostannyu-ekonomiky/

[5] Korbut, A. (2015). TaaviRyyvas: Zavdyaky reformam my staly chlenamy YeS i dosyahly ekonomichnoho zrostannya. Available at: http://tyzhden.ua/World/128133

[6] Savina, A. (2015). Elektronna Estoniya: yak zbuduvaty naysuchasnishu tsyfrovu derzhavu. Available at: http://inspired.com.ua/ideas/digital-estonia/

[7] Kramariv, T. (2011). Estons'ke ekonomichne dyvo: chomu Ukrayina nikoly ne stane skhidnoyevropeys'kym «tyhrom». Available at: http://texty.org.ua/pg/article/editorial/read/27128/Jestonske_jekonomichne_dyvo_chomu_Ukrajina_nikoly_ne

[8] Reytynh bankov Estonyy. Available at: http://www.offshore-centre.com/rejting-bankov-estonii/

[9] Naibol'shie riski dlya bankovskojsistemy Ehstoniii skhodyat iz Severnyh stran (2016). Available at: http://www.baltic-course.com/rus/finansi/?doc=126558

[10] Prognoz: v 2017 godu ehkonomika Ehstonii i ES prodolzhit rasti (2017). Available at: http:// rus.delfi.ee/daily/euroopa/prognoz-v-2017-godu-ekonomika-estonii-i-es-prodolzhit-rasti?id=76228839 